\title{
Probabilistic Seismic Hazards Analysis of Ambikapur-Chhattisgarh (India)
}

\author{
Ashish Kumar Parashar ${ }^{1}$, Sohanlal Atmapoojya ${ }^{2}$ \\ ${ }^{1}$ Department of Civil Engineering, Faculty of IT, GGV, Central University, Bilaspur, C.G. India, \\ aparashar08@gmail.com \\ ${ }^{2}$ Department of Civil Engineering, Faculty of Engineering, K.I.T.S. Ramtek, Maharashtra India, \\ atmapoojya@yahoo.com
}

\begin{abstract}
The present study reveals the seismic hazard analysis of district headquarter Ambikapur, in the state of Chhattisgarh. Usually, seismic hazard study attempts to analyze two different kinds of anticipated ground motions, "the Deterministic Seismic Hazard Analysis (DSHA)" and "the Probabilistic Seismic Hazard Analysis (PSHA)". The maximum Peak Ground Acceleration (PGA) has been estimated by using Iyengar and Raghu Kanth (2004) attenuation relationship. The regional recurrences relation is obtained by using available historical data and 33 numbers of seismic sources (liner faults) that are likely to cause ground motion, around the study area. The probabilistic seismic hazard analysis has been applied over Ambikapur, to assess the probability of exceedance for various PGA(g)values the seismic hazard curve has been developed by using Raghu Kanth and Iyengar (2007) attenuation relationship. The probability of exceedance for $\mathrm{PGA}(\mathrm{g})$ values as $0.01 \mathrm{~g}, 0.05 \mathrm{~g}, 0.10 \mathrm{~g}, 0.15 \mathrm{~g}$ for their corresponding return periods have also been assessed. The liner seismic source having length $46 \mathrm{kM}$, produced maximum peak ground motion as $0.15259 \mathrm{~g}$ for recurrence period of 100 years. For Ambikapur district headquarter the probability of exceedance for $0.1 \mathrm{~g}$ with a return period of 8788 years is estimated as $63.22 \%$. Maximum Peak Ground Acceleration value and \% probability of exceedance reflects that the seismicity of Ambikapur district headquarter is found to have exceeded from 0.1g as recommended by IS:1893 (Part 1): 2016 (Sixth Revision) for Chhattisgarh. Hence, it is recommended from present study that, Ambikapur should be included in zone III instead of zone II.
\end{abstract}

Key words : Ground Motion Attenuation, Peak Ground Acceleration, Uncertainty, Seismic Hazard Curve.

\section{INTRODUCTION}

Since the dawn of human civilization, seismic tremor is known to be one of the primary complex phenomenon that the present world is facing. Efforts are being made to develop realistic and probabilistic models, for determining the location and time of

upcoming earthquakes. It is indispensable that the after effects can be reduced to some extent. Regional seismic hazard maps that are developed, give an idea of seismic hazard vulnerability of an area. So various researchers have carried out seismic microzonation of different Indian cities and states using probabilistic approach. In seismic map of India Chhattisgarh state is located in "low" seismically active region Ambikapur, is said to be one of the oldest but prominent city there, the name being derived from the Hindu Goddess worshipped in that area. The location can be traced towards the east of central India, at $23^{\circ} 12^{\prime} \mathrm{N} 83^{\circ} 2^{\prime} \mathrm{E}$. The city is said to be a proud owner of many valuable heritage structures, outlining the precious constituents of history, culture and human evolution. There are many evidences existing to the olden construction technology, aesthetics, civilizing practices, arts, defenses and governance of the region. These ancient masonry structures were constructed based on empirical acquaintance of structural behavior by trial-and-error processes, essentially taking into consideration dead loads only. Not overlooking their bulky mass due to masonry walls, poor connections between structural elements and structural distress due to deteriorated material properties they are often found to undergo destruction. Conservation of such historical buildings from natural disasters like an earthquake becomes a paramount responsibility of the modern society, so that it may be conserved for the future generations.

\section{PIONEER RESEARCH IN INDIA}

As Peninsular India (PI) lies within intra-plate setting (a region far from well-defined plate boundaries) very little crustal deformation is expected [1]. When compared to the foothills of mighty Himalayas, earthquakes are generally less likely to occur near the plate boundaries. Although the frequency of occurrence of large earthquakes is low, their impact on civilization is high. Thus, it becomes imperative to compute the seismic hazard for Peninsular India for future 
occurrence, regarding potential ground shaking while simultaneously recognizing challenges and the intrinsic vulnerabilities [1]. However, as observed in the recent past, several notable earthquakes have occurred in various places in Peninsular India: Kutch (1819, Mw 7.8), Koyna (1967, Mw 6.3), Latur (1993, Mw 6.1), Jabalpur (1997, Mw 5.8), and Bhuj (2001, Mw 7.6), claiming thousands of lives and causing huge monetary losses due to the harm caused to the infrastructures. Early research works on seismic hazard in India by Tondon (1956) [2] and Krishna (1959) [3] is restricted to the identification of probable earthquake areas. Studies carried out by Guha (1962)[4] and Gubin (1968)[5] is based on microseismic force, consequently seismic studies of probabilistic risk carried out by Basu and Nigam (1977) [6], Kaila and Rao (1979)[7] and Khatri et al.(1984) [8]. Khatri et al. (1984) present a detailed peak ground acceleration (PGA) hazard map, describing a $10 \%$ annual probability of exceedance within 50 years. Parvez et al. (2003) did the neo-deterministic seismic evaluation for the Indian subcontinent because of simulation and computation of synthetic seismograms [9]. Jaiswal and Sinha (2007) gauge probabilistic seismic peril for Peninsular India applying the zone free approach proposed by Frankel (1995), incorporating different models with suitable weight [10]. Vipin et al. (2009) accommodates South India [11] and Menon et al. (2010) accommodates Tamilnadu [12]. Verma and Bansal (2013) audit is largely concentrated on microzonation studies directed in different Indian urban areas [13]. The National Disaster Management Authority of India (NDMA) published a report on the inclusive probabilistic seismic risk for the Indian Subcontinent [14]. In this report, India has been subdivided. In this report, India has been subdivided into 32 seismic zones with Peninsular India, containing 9 zones applying an old style zonation approach.

\section{STUDY AREA AND SEISMICITY}

Newly born state Chhattisgarh, comes under Peninsular India (PI). The state is reported as low seismic region in seismic zoning map recommended by Bureau of Indian Standard (BIS) code.

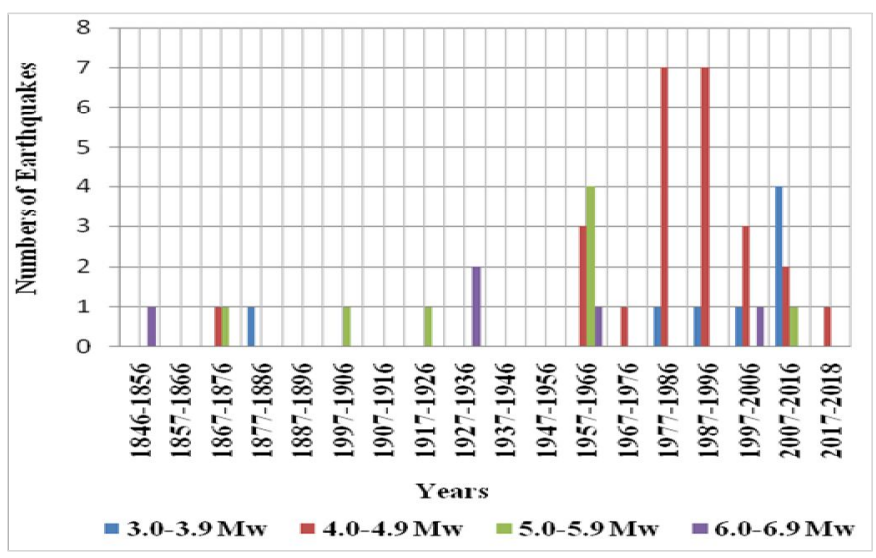

Figure 1: Past Earthquakes around Study Area
The historical earthquake data of study area collected from various research agencies of India, reported an increase in earthquake activity between the year 1996 to 2018 as shown in Figure 1. The current scenario generates the need for researchers to pay attention towards it. So the present study is focused over the Ambikapur, district Headquarter and carried out the probabilistic seismic hazard analysis for it.

\section{PROBABILISTIC SEISMIC HAZARD ANALYSIS (PSHA)}

It is well known fact that PSHA integrates the things of all upcoming tremors for all possible magnitudes, at all significant distances from the site. It allows the use of continuous, multi-valued events and models. The analysis incorporates the probability of different magnitudes or intensity of earthquakes occurring. Another advantage of probabilistic seismic hazard study is that, its outcome is an estimation of the probability of earthquake ground motions or other damage measures, occurring at the location of interest. In the past years, the use of probabilistic concepts, has incorporated acceptable uncertainties in the size, location and rate of recurrence of earthquakes and in the variation of ground motion characteristics with earthquake size and location to be explicitly taken into consideration in the assessment of seismic hazard. Probabilistic seismic hazard analysis (PSHA) [15] has been described in following four steps as shown in Figure 2, in which these uncertainties can be identified, quantified and combined in a rational manner.

1. First step is to identifying and categorizing the active earthquake sources. The probability distribution of source-to-site distances, are then obtained by combining these distributions with the source geometry.

2. The next step includes the characterization of the seismicity or temporal distribution of earthquake recurrence. The seismicity of each source is then characterized by a recurrence relationship, which specifies the average rate, at which an earthquake of different size will be exceeded. The recurrence relationship may accommodate the maximum size earthquake.

3. The ground motion produced at the site by earthquake of any possible size occurring at any possible point, in each source must be determined with the use of predictive relationships. The uncertainty inherent in the predictive relationship is also considered in a PSHA.

4. Finally, the uncertainties in earthquake location, earthquake size, and ground motion parameter prediction are combined, to obtain the probability of occurrence. 


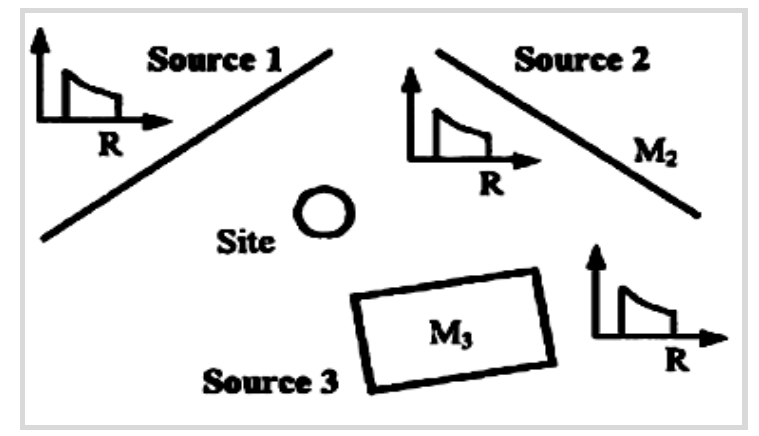

(a) Step 1

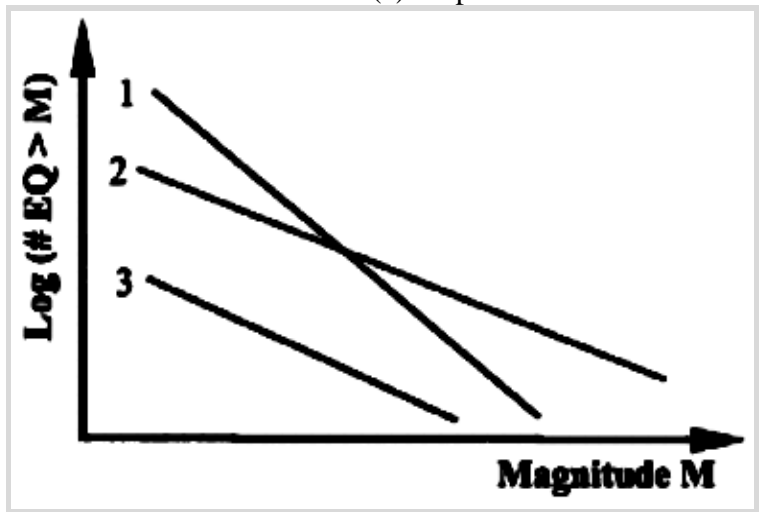

(b) Step 2

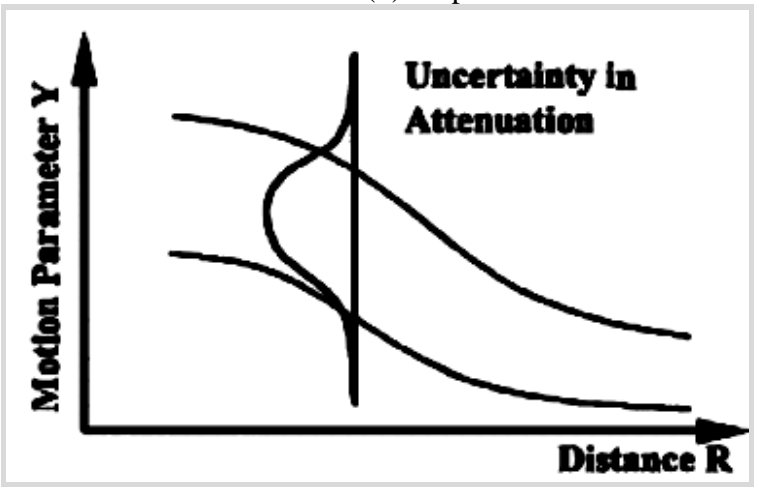

(c) Step 3

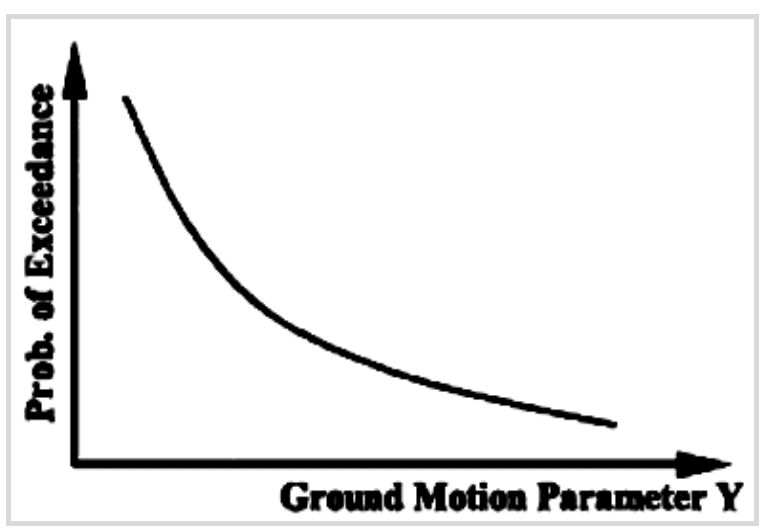

(d) Step 4

Figure 2: Steps of Probabilistic Seismic Hazard Analysis (PSHA)

\subsection{Identification and Characterization of Earthquake Sources}

In the present research, identified faults were taken from the Seismotectonic Atlas developed by Survey of India (SEISAT 2000) [16]. The Seismotectonic Map for district headquarter Ambikapur as shown in Figure 3, is prepared keeping the headquarter at the centre of the circle, with a radius of 300 $\mathrm{km}$. The 33 nos. of faults within the radius were identified and marked. All faults having fault length $\mathrm{L}_{\mathrm{f}} \geq 25 \mathrm{~km}$ are consider for analysis.

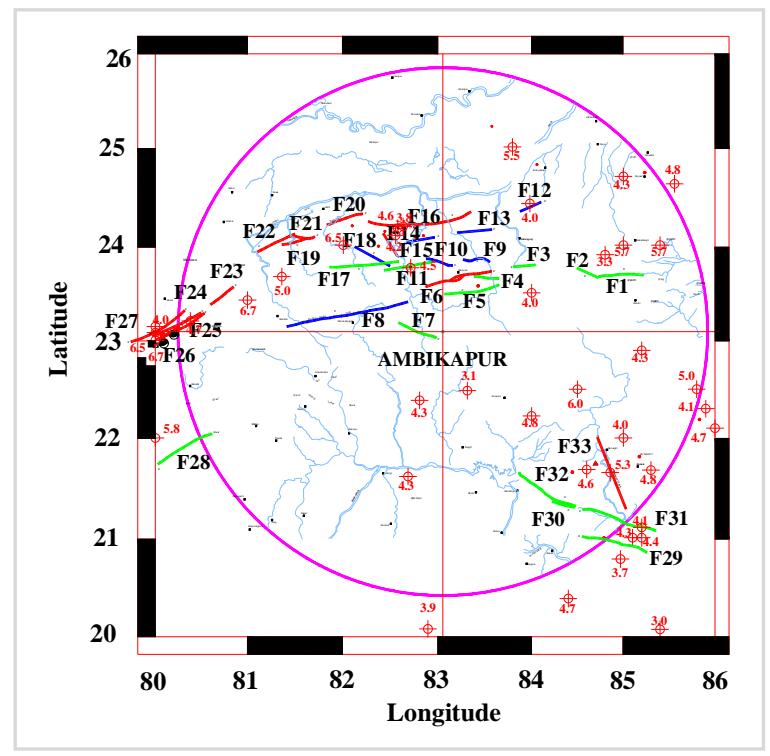

Figure 3: Seismotectonic Digitized Fault Map of District Headquarter Ambikapur

\subsection{Recurrence Relationship}

Gutenberg-Richter (1956) have developed a recurrence relation. For estimating, the ground motions for earthquakes the seismic parameters should be assessed. These seismic parameters include "a" and "b" parameters of the Gutenberg-Richter [17]. The recurrence relation is given as

$$
\log 10 \mathrm{~N}=\mathrm{a}-\mathrm{b}^{*} \mathrm{Mw}
$$

A complete earthquake catalogue is needed for presenting the seismicity pattern of a region. The seismic recurrence rate can be evaluated correctly if the collected data of the earthquake events are complete. Therefore, the historical earthquake data from year 1846 to year 2018 were used for completeness analysis [18]. 
Ashish Kumar Parashar et al., International Journal of Emerging Trends in Engineering Research, 9(2), February 2021, 83 - 91

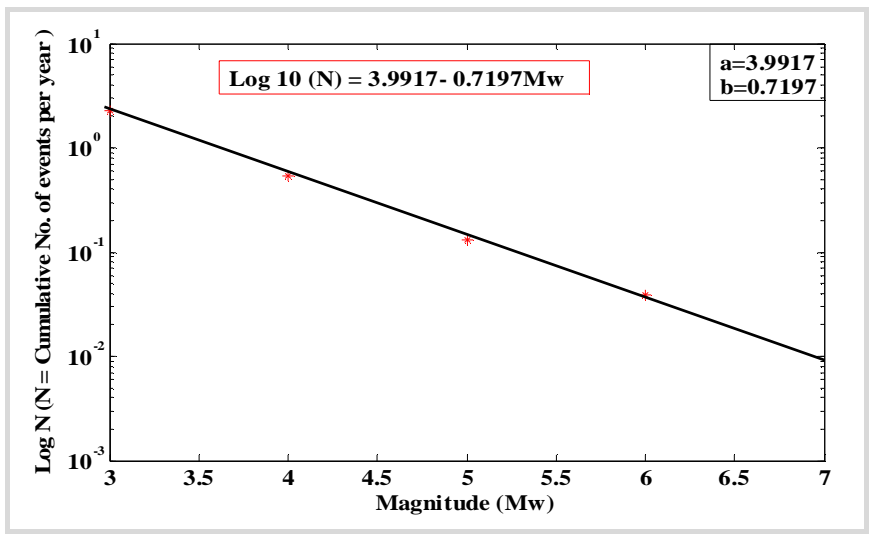

Figure 4: Frequency-Magnitude Relationship for District Headquarter Ambikapur

Anbazhagan et al. (2009) described the detailed procedure for completeness analysis as based on Stepp (1972) method [19]. From the completeness analysis, it can be summarized that the earthquake catalogue for the region has been completed for the last 20 years for a moment magnitude $(\mathrm{Mw}) \leq 3.0$ and for last 135 years for $\mathrm{Mw} \leq 6$. The "a" and " $\mathrm{b}$ " parameters were determined for Ambikapur region. The $b$ value for the Ambikapur region is found to be 0.7197 from Figure 4.

\subsection{Ground Motion Attenuation}

Attenuation relationships are empirical descriptions providing the median and standard deviation of various intensity measures of the strong ground motion, assumed to be log-normally distributed, in terms of earthquake size, distance, source characteristic and site conditions [20]. Iyengar and Raghu Kanth (2004) simulated available strong motion records in Peninsular India and suggested an empirical attenuation relationship, which is a function of magnitude and

source to site distance by covering bedrock and soil conditions [21]. The attenuation equation given as:

In $(\mathrm{PGA} / \mathrm{g})=\mathrm{C}_{1}+\mathrm{C}_{2}(\mathrm{~m}-6)+\mathrm{C}_{3}(\mathrm{~m}-6)^{2}-\ln (\mathrm{R})-\mathrm{C}_{4}(\mathrm{R})+$ $\ln (\varepsilon)$----------------------(2)

$\mathrm{C}_{1}=1.6858, \mathrm{C}_{2}=0.9241, \mathrm{C}_{3}=0.0760, \mathrm{C}_{4}=0.0057, \mathrm{R}=$ Hypo central distance, $\mathrm{m}=$ magnitude, $\ln \varepsilon=0.4648$.

Table 1: Hypo Central Distance and Maximum Magnitude For key seismic Sources for Study Area

\begin{tabular}{|c|c|c|c|c|c|}
\hline $\begin{array}{c}\text { Fault } \\
\text { No. }\end{array}$ & $\begin{array}{c}\text { Fault } \\
\text { Length } \\
\mathbf{( L}_{\mathbf{f}} \mathbf{)} \text { in } \\
\mathbf{k M}\end{array}$ & $\begin{array}{c}\text { Minimum } \\
\text { Map } \\
\text { Distance } \\
(\mathbf{d}) \text { in } \\
\mathbf{k M}\end{array}$ & $\begin{array}{c}\text { Hypo } \\
\text { Central } \\
\text { Distance } \\
(\mathbf{R}) \text { in } \\
\mathbf{k M}\end{array}$ & $\begin{array}{c}\text { Observed } \\
\text { Magnitude } \\
\left.\mathbf{( M}_{\mathbf{O}}\right)\end{array}$ & $\begin{array}{c}\text { Maximum } \\
\mathbf{M a g n i t u d e} \\
\left.\mathbf{( M}_{\text {max }}\right)\end{array}$ \\
\hline F1 & 51 & 187.931 & 188.197 & 3.3 & 4.7 \\
\hline F4 & 28 & 72.365 & 73.053 & 4.0 & 4.5 \\
\hline F7 & 46 & 10.314 & 14.366 & 4.5 & 5.0 \\
\hline F8 & 140 & 52.428 & 53.374 & 6.7 & 7.2 \\
\hline F31 & 86 & 182.619 & 182.893 & 4.4 & 5.0 \\
\hline
\end{tabular}

Table 2: Peak Ground Acceleration values for Key Seismic Sources for Study Area

\begin{tabular}{|c|c|c|c|c|c|}
\hline \multirow{2}{*}{$\begin{array}{c}\text { Fault } \\
\text { No. }\end{array}$} & \multirow{2}{*}{\begin{tabular}{|c|} 
Fault \\
Length \\
in \\
kM
\end{tabular}} & \multirow{2}{*}{\begin{tabular}{|c} 
Hypo \\
Central \\
Distance \\
$(\mathbf{R})$ in $\mathrm{kM}$
\end{tabular}} & \multirow{2}{*}{$\begin{array}{l}\text { Magnitude } \\
\text { Recurrence } \\
\text { Periods of } \\
100 \text { Years }\end{array}$} & \multicolumn{2}{|c|}{$\begin{array}{c}\text { Peak Ground } \\
\text { Acceleration (g) }\end{array}$} \\
\hline & & & & $\begin{array}{c}50 \\
\text { Percentile }\end{array}$ & $\begin{array}{c}84 \\
\text { Percentile }\end{array}$ \\
\hline F1 & 51 & 188.197 & 4.654 & 0.00247 & 0.00393 \\
\hline $\mathrm{F} 4$ & 28 & 73.053 & 4.443 & 0.00962 & 0.01530 \\
\hline F7 & 46 & 14.366 & 4.741 & 0.09587 & 0.15259 \\
\hline F8 & 140 & 53.374 & 5.342 & 0.03930 & 0.06255 \\
\hline F31 & 86 & 182.893 & 4.954 & 0.00365 & 0.00580 \\
\hline
\end{tabular}

The maximum magnitude is estimated as shown in Table 1, using methods given by Wells \& Coppersmith [22] and Gupta [23]. The Hypo Central Distance (R) in $\mathrm{kM}$ is calculated as $R=\sqrt{d^{2}+F^{2}}$ where, the focal depth for all seismic sources is taken as $10 \mathrm{kM}$. The attenuation relationship given by Iyengar and Raghu Kanth (2004) for Peninsular India is used to assess the Peak Ground Acceleration (PGA) for key faults as illustrated in Table 2.

\subsection{Uncertainty in Sources to Site Distance}

In the PSHA, the uncertainty involves distance of each source to the site. In a seismogenic source, every point/segment belonging to the source is capable of getting ruptured and generating an earthquake. The geometries of seismic sources depend on the tectonic processes involved in their formation. As earthquakes are customarily assumed to be uniformly distributed, within a particular fault or lineaments, a uniform distribution of source to site distance is expressed in ground motion parameter [24], in terms of some measure of source to site distance; the uncertainty must be described with respect to the appropriate distance parameter. The ambiguity involved in the source to site distance is described by a probability density function. Thus the relative orientation of each source with respect to the site becomes important.

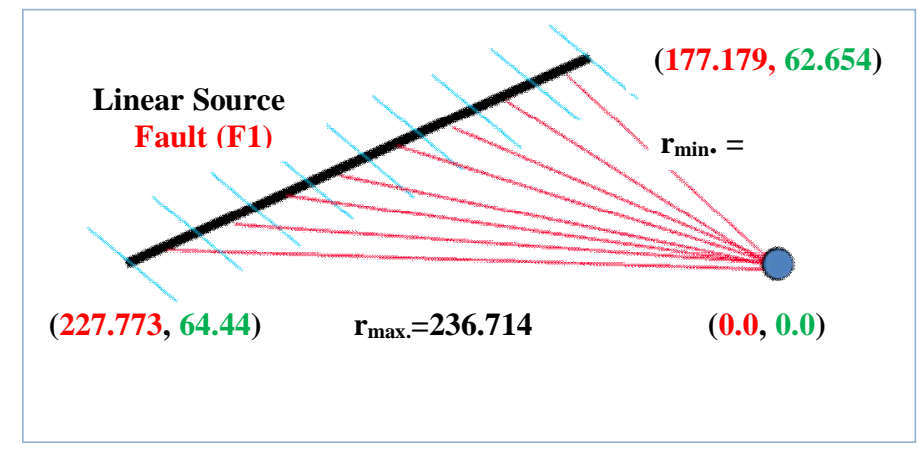

Figure 5: Source-to-Site Distance and Coordinates for Fault F1

For the estimation for probability density function the shortest and longest distance of all the sources from the site for the district headquarters has been considered. The earthquakes are considered equally likely to occur at any location along the length of the linear source since the attenuation relations 
involve this source-to-site distance for predicting ground motion. All possible source-to-site distances need to be considered by dividing the whole length of the fault into smaller "N" number of segments. The accuracy increases with increasing number of segments. The uncertainty in source-to-site distance is described [25] by a probability density function following Kramer (2015) [26], as describe below.

$$
f_{R}(r)=\frac{r}{L_{f} \sqrt{r^{2}-r^{2}{ }_{\text {min }}}}
$$

The closest $\left(\mathrm{r}_{\min }\right)$ and longest $\left(\mathrm{r}_{\max }.\right)$ possible source-to-site distance is divided into $N_{R}=10$ distance intervals of length $\left(r_{\max }-r^{-}-\mathrm{min}_{\mathrm{n}}\right) / \mathrm{N}_{\mathrm{R}}$ or $\left(\mathrm{r}_{\max }-\mathrm{r}_{\min }\right) / 10$. For an example for the Fault F1, Length $51 \mathrm{~km}$ for Ambikapur, the shortest possible source-to-site distance is $187.931 \mathrm{kM}$ and the longest is $236.714 \mathrm{kM}$ from Figure 5. As the range is divided into $\mathrm{N}_{R}$ $=10$ intervals of length $(236.714-187.931) / 10=4.8743 \mathrm{~km}$. Further, this source is divided into 1000 number of equal length segments and these segments are distributed in 10 intervals accordingly. A computer programme in MATLAB has been developed for estimation of source-to-site distance probability density function and it is graphically represented by Fig. 6(a),(b),(c),(d) \& (e) for corresponding key Faults F1, F4, F7, F8 and F31.

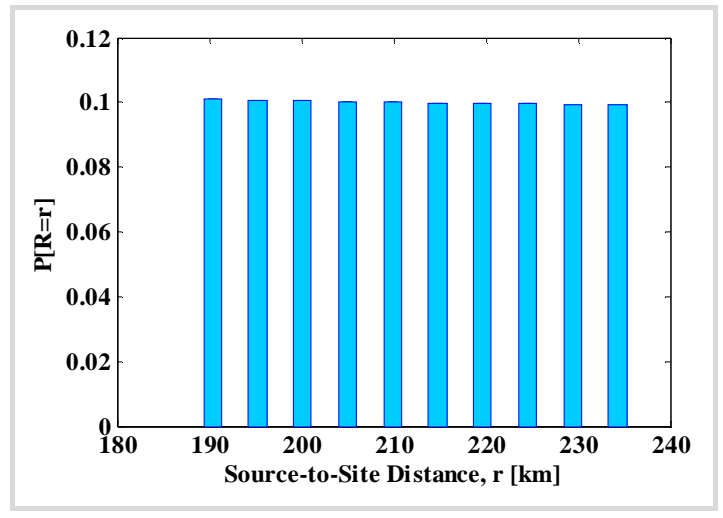

(a) Fault 1

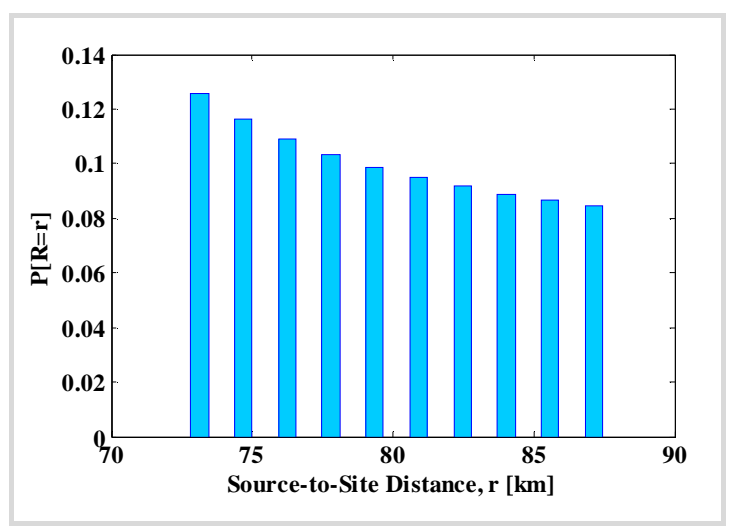

(b) Fault 4

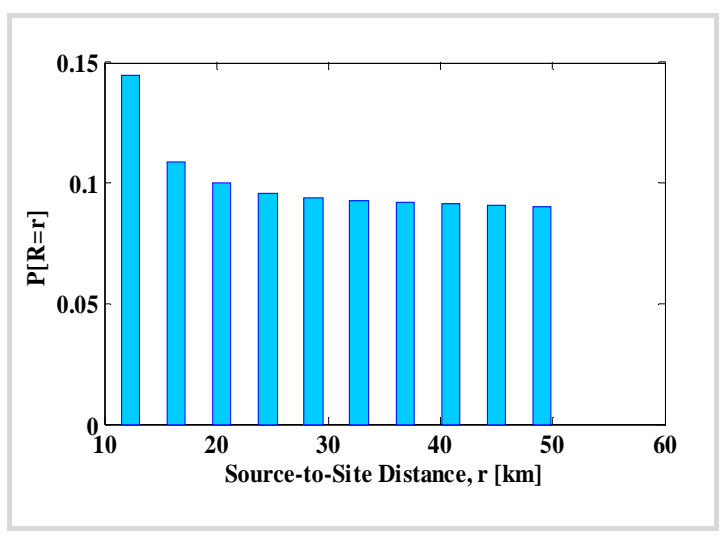

(c) Fault 7

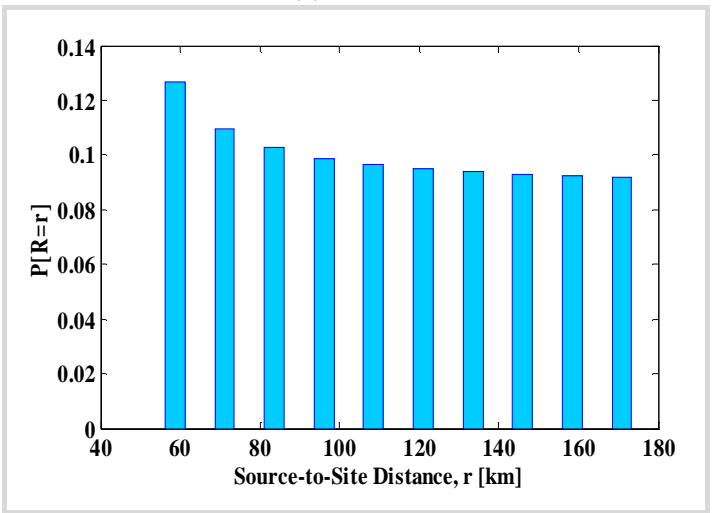

(d) Fault 8

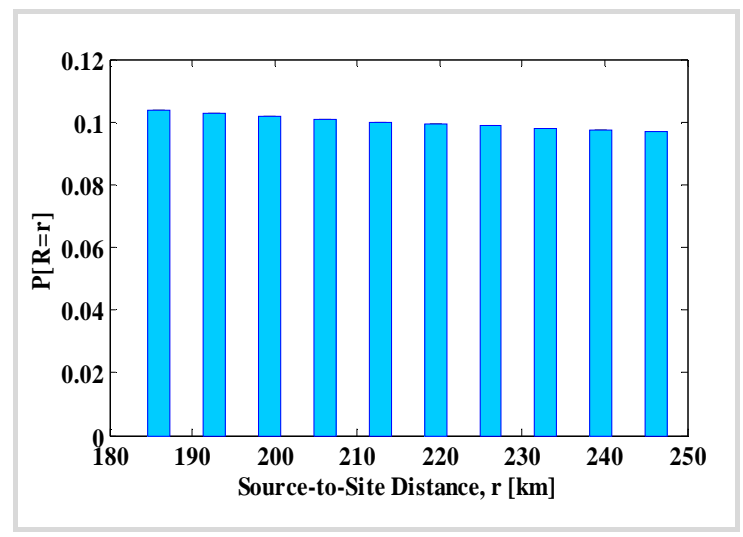

(e) Fault 31

Figure 6: Probability Distribution for source to site distance for District Headquarter Ambikapur

\subsection{Uncertainty in Magnitude}

For active seismic sources, the important parameter is its magnitude [27]. Therefore, it is necessary to estimate the maximum magnitude for each active seismic source. In the PSHA the basic assumption is that, the future seismicity of a regain can be predicated based on past seismicity of that 
Ashish Kumar Parashar et al., International Journal of Emerging Trends in Engineering Research, 9(2), February 2021, 83 - 91

region. The uncertainty in the magnitude of earthquake plays a vital role for estimation of probability of occurrence of a particular magnitude with a given range. The probability of incidence of an earthquake of a particular magnitude is obtained by using the probability density function. Here, the density function with an upper $\left(\mathrm{m}_{\max }\right)$ and lower $\left(\mathrm{m}_{\min }\right)$ magnitude is given as below:

$$
f_{M}(m)=\frac{\beta e^{-\beta\left(m-m_{\min }\right)}}{\left[1-e^{-\beta\left(m_{\max }-m_{\min }\right)}\right]} \quad m_{\min } \leq m \leq m_{\max }
$$

The probability of the magnitude with lower and upper bound $\mathrm{m} 1, \mathrm{~m} 2$ respectively is given by:

$P\left[m_{1}<m<m_{2}\right]=\int_{m_{1}}^{m_{2}} f_{M}(m) d m \approx f_{M}\left(\frac{m_{1}+m_{2}}{2}\right) x\left(m_{2}-m_{1}\right)$

The process is illustrated by taking the example of Fault F1 which has $\mathrm{m}_{\min }=3.0$ and $\mathrm{m}_{\max }=4.7$. By dividing this range into $\mathrm{NM}=10$ intervals of size $(4.7-3.0) / 10=0.17$ each, the lowest magnitude interval is from $m_{1}=3.0$ to $m_{2}=3.17$. The probability that the magnitude will fall within this interval using Equation (4) is:

$P[3.0<m<3.17]=\frac{1.6675 * e^{-1.67 \%(2.063-10)}}{1-e^{-1.677 \% *(470-16)}} *(3.17-3.0)=0.26$

These probabilities are interpreted as the probability of occurrence of an earthquake of magnitude equal to the mid-point of the interval $(\mathrm{m}=3.085$ in the Fault F1).

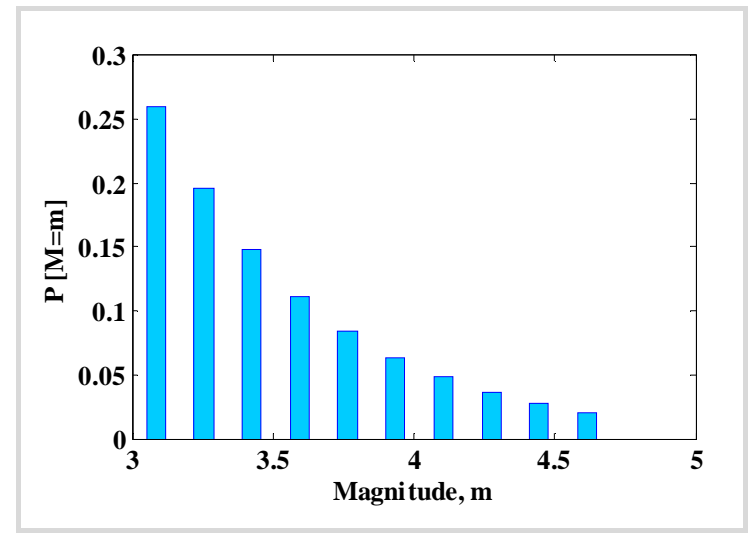

(a) Fault 1

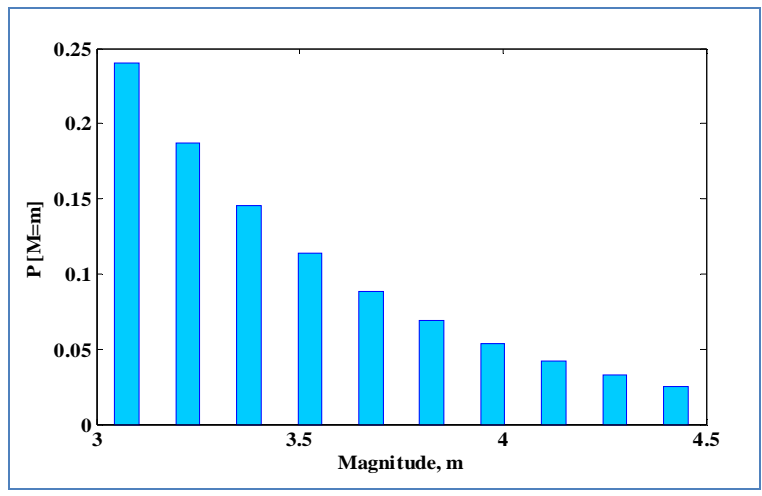

(b) Fault 4

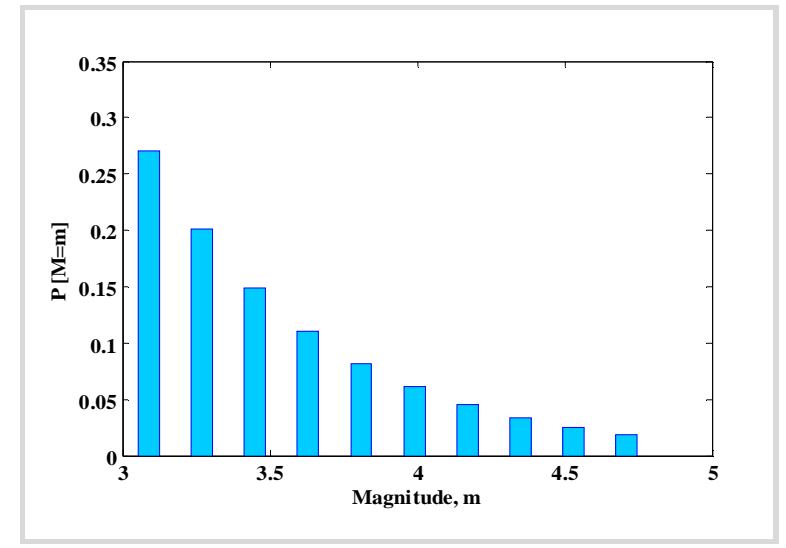

(c) Fault 7

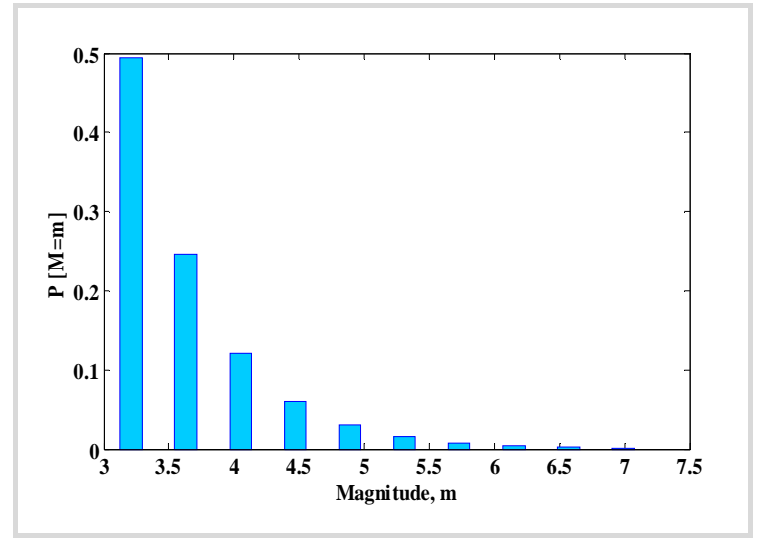

(d) Fault 8

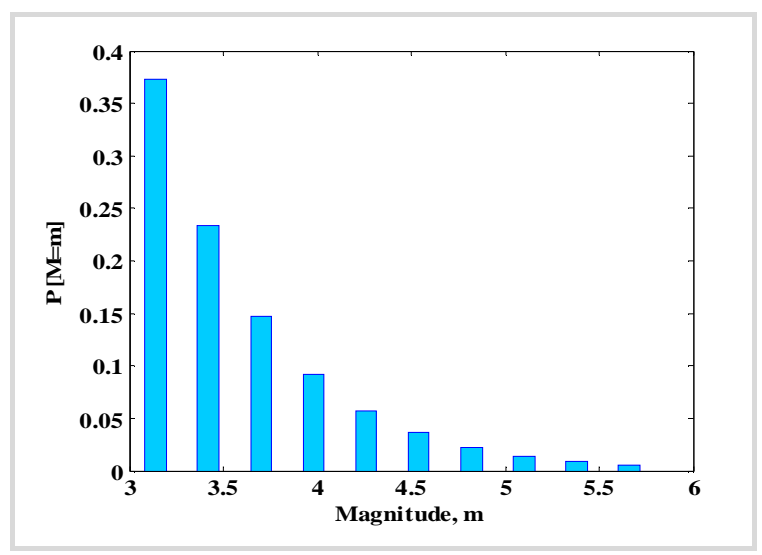

(e) Fault 31

Figure 7: Probability Distribution for Magnitude for key Fault for District Headquarter Ambikapur

A computer programme in MATLAB has been developed for estimation of magnitude probability density function and it is graphically represented by Fig. 7(a),(b),(c),(d) \& (e) for corresponding Faults F1, F4, F7, F8 and F31 for district headquarter Ambikapur. 
Ashish Kumar Parashar et al., International Journal of Emerging Trends in Engineering Research, 9(2), February 2021, 83 - 91

\subsection{Seismic Hazard Curve}

In seismic hazard assessment, the ground motion computation is the key parameter and computation is based on uncertainties like source to site distance and magnitude [28]. For accounting this uncertainty in the seismic hazard investigation, the probability distribution of the ground motion parameter $\mathrm{Y}$, must be evaluated as a function of earthquake source magnitude and the location of the rupture relating to the site.

The seismic hazard curve is the final outcome of PSHA which defines the probability of exceedance of $Y$ from a certain value $\mathrm{y}^{*}$, for a particular source-to-site distance, $\mathrm{r}$ and an earthquake of magnitude $m$ is expressed as: Effects $-\mathrm{P}[\mathrm{Y}>\mathrm{y} *$ $\mathrm{m}, \mathrm{r}]=1-\mathrm{Fy}\left(\mathrm{y}^{*}\right)$. The mean annual rate of exceedance is defined as below:

$\lambda_{y^{*}}=\sum_{i=1}^{N_{s}} \sum_{j=1}^{N_{M}} \sum_{k=1}^{N_{R}} v_{i} \iint P\left[Y>y^{*} \mid m_{j}, \boldsymbol{r}_{k}\right] P\left[M=m_{j}\right] P\left[R=r_{k}\right]$

The total 33 active faults were used to develop the seismic hazard curve as shown in Figure 8 for district headquarter Ambikapur. The attenuation model of Raghukanth and Iyengar (2007) [29] has been used for development of hazard curve for Ambikapur. For generating seismic hazard curve, a computer program in MATLAB is developed.

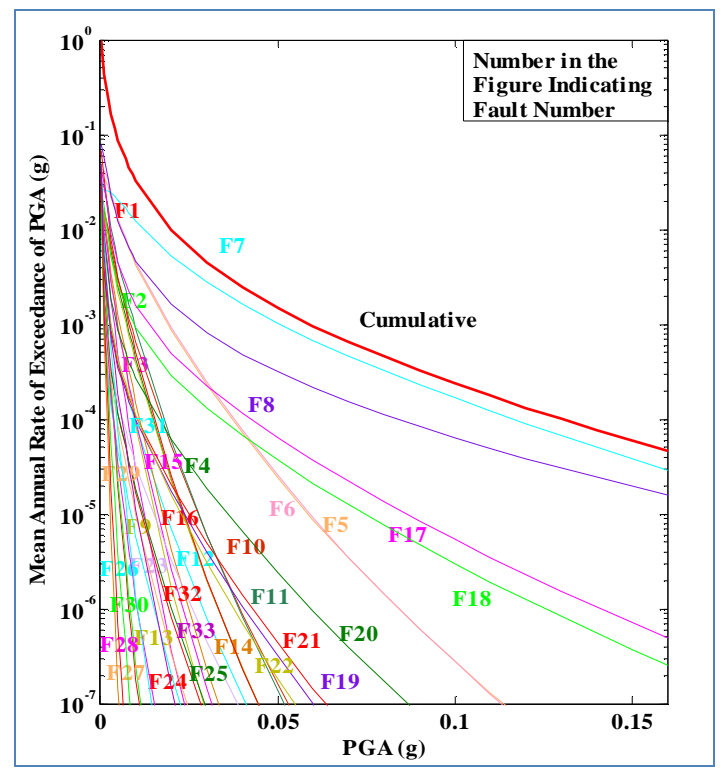

Figure 8: Hazard Curve for District Headquarter Ambikapur at Bedrock Level

Table 3: Estimated Return Period for various PGA (g) values for Key Seismic Sources for District Headquarter Ambikapur

\begin{tabular}{|c|c|c|}
\hline $\begin{array}{c}\text { Probability of } \\
\text { Exceedance } \\
\text { For PGA (g) }\end{array}$ & $\begin{array}{c}\text { Return Period } \\
\text { (Years) }\end{array}$ & Probability (\%) \\
\hline $0.01 \mathrm{~g}$ & 33 & 63.58 \\
\hline $0.05 \mathrm{~g}$ & 1017 & 63.24 \\
\hline $0.10 \mathrm{~g}$ & 8788 & 63.22 \\
\hline $0.15 \mathrm{~g}$ & 48781 & 63.22 \\
\hline
\end{tabular}

For various PGA values the Mean Annual Rate of Exceedance [30] were calculated and then estimated the return periods respectively, as illustrated in Table 3 .

\subsection{Probability of Exceedance}

Assuming the Poisson's process for ground motion occurrences, the probability of occurance of an event $y^{*}$, is related to annual frequency of exceedance of the peak ground motion and the exposure time $\mathrm{T}$ and given as:

$\mathrm{P}\left[\mathrm{YT}>\mathrm{y}^{*}\right]=1-\mathrm{e}-\lambda \mathrm{y}^{*} \mathrm{~T}$

Table 4: Percentage Probability for various Return Periods for District headquarter Ambikapur

\begin{tabular}{|c|c|c|}
\hline $\begin{array}{c}\text { PGA(g) } \\
\text { Values }\end{array}$ & $\begin{array}{c}\text { Mean Annual Rate of } \\
\text { Exceedance }\end{array}$ & $\begin{array}{c}\text { Return Period } \\
\text { (Years) }\end{array}$ \\
\hline $0.01 \mathrm{~g}$ & 0.0306000 & 33 \\
\hline $0.05 \mathrm{~g}$ & 0.0009838 & 1017 \\
\hline $0.10 \mathrm{~g}$ & 0.0001138 & 8788 \\
\hline $0.15 \mathrm{~g}$ & 0.0000205 & 48781 \\
\hline
\end{tabular}

The percentage probabilities are estimated for probability of exceedance for various PGA (g) values, with their corresponding return period and as tabulated in Table 4 .

Table 5: Seismic Zone Factor, Z, IS 1893 (Part 1): 2016

(Clause 6.4.2)

\begin{tabular}{|c|c|c|c|c|}
\hline $\begin{array}{c}\text { Seismic } \\
\text { Zone }\end{array}$ & II & III & IV & V \\
\hline $\begin{array}{c}\text { Seismic } \\
\text { Intensity }\end{array}$ & Low & Moderate & Severe & $\begin{array}{c}\text { Very } \\
\text { Severe }\end{array}$ \\
\hline Z & 0.10 & 0.16 & 0.24 & 0.36 \\
\hline
\end{tabular}

India is divided in five seismic zones for each zone a zone factor Z, as illustrated in Table 5 and It is given by IS 1893 (Part 1): 2016 (Sixth Revision) [31]. On the basis of Peak Ground Acceleration (PGA) zone factors values are given as tabulated in Table 5. The newly born state Chhattisgarh comes under zone II and its zone factor is $0.1 \mathrm{~g}$. For $0.1 \mathrm{~g}$ the estimated return period from present study is 8788 years. For above return period with a probability of exceedance for $0.1 \mathrm{~g}$, the chance of probability is $63.22 \%$.

\section{Conclusions}

Thus the present study estimates the seismic hazard of district headquarter Ambikapur, using probabilistic analysis, considering all the 33 faults, that are likely to cause ground motion, within and around $300 \mathrm{~km}$ radius, of Ambikapur. The regional recurrences relation was established, based on historical earthquake data, using Stepp's method. The b values depicted in Fig. 4, is 0.7197. For calculating the PGA 
(g) values for key faults, Iyengar and Raghu Kanth (2004), attenuation relationship is used. Among the key faults, fault no. F7 is the closest fault having fault distance as $10.314 \mathrm{kM}$ from the headquarter Ambikapur. The active seismic sources (F7) produced maximum Peak Ground Acceleration as $0.09587 \mathrm{~g}$ and $0.15259 \mathrm{~g}$ for 50 Percentile and 84 Percentile respectively [32]. The uncertainties in the location, magnitude and recurrence of all faults have been incorporated and graphically presented in hazard curve as shown in Fig. 8. The PGA values for probability of exceedance for $0.01 \mathrm{~g}$, $0.05 \mathrm{~g}, 0.10 \mathrm{~g}$ and $0.15 \mathrm{~g}$ with their corresponding return periods were found as 33 years, 1017 years, 8788 years and 48781 years respectively. As illustrated that the Peak Ground Acceleration (PGA) for seismic source F7, the estimated value is $0.15259 \mathrm{~g}$

for 84 Percentile is higher than the zone factor value of $0.1 \mathrm{~g}$ for zone II as recommended by IS 1893 (Part 1): 2016 (Sixth Revision). On the other hand for same seismic source (F7) the return period found to be 8788 years with a probability of exceedance for $0.1 \mathrm{~g}$ the chance of probability is estimated as $63.22 \%$ which is very high. Therefore, the study clearly reflects that, the seismicity for Ambikapur has increased from low seismic zone (II) to moderate zone (III). The outcome of the present research highlights the fact that the Civil Engineering structures in and around the Ambikapur should be designed as earthquake resistant. The municipal authorities should to restructure the bylaws for planning, and norms for designing of Civil Engineering structures. It is further recommended that to execute the IS Code guidelines at the time of construction also.

\section{REFERENCES}

1. S. G. Patil, G. R. Dodagoudar, and Arun Menon. Seismic Input Ground Motions at Historical Site of Vijayapura, South India, Sixth International Conference on Recent Advances in Geotechnical Earthquake Engineering and Soil Dynamics, IIT Roorkee Extension Centre, 20 Knowledge Park II, Greater Noida, India, August 2016, pp. 1-6.

2. A. N. Tandon. Zones of India liable to earthquake damage, Indian Journal of Meteorological Geophysics, Vol.10, pp. 137-146, July 1956.

3. J. Krishna. Seismic Zoning of India, Proc. Earthquake Engineering Seminar, Roorkee, 1959, pp. 32-38.

4. S. K. Guha. Seismic regionalization of India, Proceedings of Second Symposium on Earthquake Engineering, Roorkee, India, 1962, pp.191-20.

5. I. E. Gubin. Seismic zoning of Indian peninsula, Bull. Int. Inst. Seismol. Earthquake Eng., Vol. 5, pp. 109-139, 1968.

6. S. Basu, and N. C. Nigam. Seismic risk analysis of Indian peninsula, Proceedings of Sixth World Conference on Earthquake Engineering, New Delhi. Vol. 1, 1977, pp. 782-788.
7. K. L. Kaila, and N. M. Rao, Seismic zoning maps of Indian subcontinent, Geophys. Res. Bull., Vol. 17, pp. 293-301, 1979.

8. K.N. Khattri, A.M. Rogers, D.M. Perkins, and S.T. Algermissen. A seismic hazard map of India and adjacent areas, Tectonophysics, Vol. 108(1-2), pp. 93-134, September 1984.

9. I. A. Parvez, F. Vaccari, and G. F. Panza. A deterministic seismic hazard map of India and adjacent areas, Geophys. J. Int. Vol. 155(2), pp. 489-508, October 2003.

10. K. Jaiswal, and R. Sinha. Probabilistic seismic-hazard estimation for peninsular India, Bulletin of the Seismological Society of America, Vol. 97, pp. 318-330, February 2007.

11. K. S. Vipin, P. Anbazhagan, and T. G. Sitharam. Estimation of peak ground acceleration and spectral acceleration for South India with local site effects: probabilistic approach, Nat. Hazards Earth Syst. Sci., Vol. 9, pp. 865-878, June 2009.

12. A. Menon, T. Ornthammarath, M. Corigliano, and C. G. Lai. Probabilistic seismic hazard macrozonation of Tamil Nadu in southern India, Bulletin of the Seismological Society of America, Vol. 100(3), pp. 1320-1341, June 2010.

13. M. Verma, and B. K. Bansal. Seismic hazard assessment and mitigation in India: an overview, International Journal of Earth Sciences (Geol Rundsch), Vol. 102, pp. 1203-1218, March 2013.

14. Development of probabilistic seismic hazard map of India; Technical Report by National Disaster Management Authority, Government of India, NDMA 2010.

15. A. C. Lindholm, I. A. Parvez, and D. Kuhn. Probabilistic earthquake hazard assessment for Peninsular India, Journal of Seismology, Vol. 20 (2), pp. 629-653, January 2016.

16. SEISAT: Seismotectonic Atlas of India; Geological Survey of India, New Delhi, 2000.

17. B. Gutenberg, and C.F. Richter. Earthquake magnitude Intensity, energy and acceleration, Bulletin of the Seismological Society of America, Vol. 46(2), pp. 105-145, April 1856.

18. P. Anbazhagan, and T. G. Sitharam. Estimation of Ground Response Parameters and Comparison with Field Measurements, Indian Geotechnical Journal, Vol. 39(3), pp. 245-270, July 2009.

19. J. C. Stepp. Analysis of the completeness of the earthquake sample in the Puget Sound area and its effects on statistical estimates of earthquakes hazard, Proc.Int. Conf. Microzonation for Safer Construct, Res. Appl., Seattle, Washington, Vol. 64(4), 1972, pp. 1189-1207.

20. N. N. Singh, Deviprasad B. S., P. H. Krishna, and G. Kalyan Kumar. Probabilistic seismic hazard analysis for warangal considering single seismogenic zoning, 
50th Indian Geotechnical Conference, Pune, Maharashtra, India, December 2015.

21. R. N. Iyengar, and S. T. G. Raghu Kanth. Attenuation of Strong Ground Motion in Peninsular India, Seismological Research Letters, Vol. 75, pp. 530-540, July 2004.

22. D. L. Wells, and K. J. Coppersmith. New empirical relationships among magnitude, rupture length, rupture area, and surface displacement, Bulletin of the Seismological Society of America, Vol. 84 (4), pp. 974-1002, August 1994.

23. I. D. Gupta. The state-of-the-art in seismic hazard analysis, Journal of Earthquake Technology, Vol. 39(4), pp. 311-346, December 2002.

24. P. Varga. Geodetic Strain Observations and Return Period of the Strongest Earthquakes of a Given Seismic Source Zone, Pure and Applied Geophysics, Vol. 168, pp. 289-296, June 2010.

25. A. Radu, and M. Grigoriu. An earthquake-source-based metric for seismic fragility analysis, Bull Earthquake Eng., Vol. 16, pp. 3771-3789, March 2018.

26. S. L. Kramer. Geotechnical Earthquake Engineering, Prentice-Hall, Upper Saddle River, New Jersey, May 2015.

27. P. Anbazhagan T. G. Sitharam, and K. S. Vipin. Site classification and estimation of surface level seismic hazard using geophysical data and probabilistic approach, Journal of Applied Geophysics, Vol. 68 (2), pp. 219-230, June 2009.

28. E. I. Katsanos, A. G. Sextos, and G. D. Manolis. Selection of earthquake ground motion records: A state-of-the-art review from a structural engineering perspective, Soil Dynamics and Earthquake Engineering, Vol. 30(4), 157-169, April 2010.

29. S T G Raghu Kanth, and R N Iyengar. Estimation of seismic spectral acceleration in Peninsular India, $J$. Earth Syst. Sci., Vol. 116(3), pp. 199-214, June 2007.

30. H. S. Mandal, A. K. Shukla, P. K. Khan, and O. P. Mishra. A New Insight into Probabilistic Seismic Hazard Analysis for Central India, Pure and Applied Geophysics, Vol. 170, pp. 2139-2161, April 2013.

31. Indian Standard Code 1893-2016. Criteria for Earthquake Resistance Design of Structures, Part-1: General Provisions and Buildings, Sixth revision, Bureau of Indian Standards, New Delhi, 2016.

32. A. K. Parashar, and S.L. Atmapoojy. Probabilistic Seismic Hazard Assessment of Major Dams of Chhattisgarh State (India), International Journal of Scientific \& Technology Research, Vol. 9(3), pp. 2290-5595, March 2020. 